\title{
The Structural Variety of DNA-DPPC-Divalent Metal Cation Aggregates: SAXD and SANS Study
}

\author{
Daniela Uhríkováa $^{\text {, Petra Pullmannováa }}{ }^{\mathrm{a}}$, Norbert Kučerka ${ }^{\mathrm{ab}}$, Sérgio S. Funari ${ }^{\mathrm{c}}$, José Teixeira ${ }^{\mathrm{d}}$ and \\ Pavol Balgavýa \\ ${ }^{a}$ Faculty of Pharmacy, Comenius University, Odbojárov 10, 83232 Bratislava, Slovakia \\ ${ }^{b}$ Canadian Neutron Beam Centre, National Research Council, Chalk River, Ontario KOJ 1PO Canada \\ ${ }^{c}$ HASYLAB, DESY, Notkestr. 85, 22603 Hamburg, Germany \\ ${ }^{d}$ Laboratoire Léon Brillouin (CEA-CNRS), CEA Saclay, 91191 Gif-sur-Yvette Cedex, France
}

\begin{abstract}
We examine the structure of aggregates formed due to DNA interaction with dipalmitoylphosphatidylcholine (DPPC) in presence of $\mathrm{Ca}^{2+}$ and $\mathrm{Zn}^{2+}$ using small-angle synchrotron X-ray diffraction (SAXD) and neutron scattering (SANS). SAXD shows structural heterogeneity as a function of the cation concentration and temperature: At low cation concentration $(\sim 1 \mathrm{mM})$, aggregates show two DPPC phases, one with a lateral segregation of DNA and cation, while higher cation concentration improves the DNA packing and the condensed lamellar phase is observed in DNA+DPPC+20 mM ion ${ }^{2+}$ aggregates. The SANS detected the dissolution of the condensed lamellar phase into unilamellar $\mathrm{DPPC}+\mathrm{Zn}^{2+}$ vesicles due to gel $\rightarrow$ liquid-crystal phase transition in

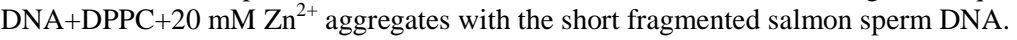

\section{Introduction}

Neutral phosphatidylcholine (PC) lipid bilayers in presence of divalent metal cations spontaneously form vesicles with a positive surface charge. Due to their interaction with DNA polyanion, colloidal aggregates with an internal organized structure are formed. These aggregates are potential DNA delivery vectors [1].

Different experimental methods were used to study physico-chemical properties of $\mathrm{DNA}+\mathrm{PC}+\mathrm{ion}^{2+}$ aggregates: light scattering [2], ESR and microcalorimetry [3-5], turbidimetry and fluorescence spectrophotometry [6,7]. Electron micrographs [8] and small angle X-ray diffraction [911] confirmed the internal organized structure of aggregates.

Structural polymorphism of DNA+PC+cation $\left(\mathrm{Ca}^{2+}, \mathrm{Mg}^{2+}\right)$ as a function of cation concentration and temperature were examined in our previous works $[12,13]$. The binding site for cations is near the negative phosphate group of the $\mathrm{P}^{-}-\mathrm{N}^{+}$dipole of phospholipid headgroup $[14,15]$. Neutralizing negative charge of phosphate group, the lipid bilayer becomes positively charged, and due to electrostatic interaction with the negatively charged phosphate groups of DNA, the aggregate is formed. Divalent metal cations bind rather weakly to zwitterionic lipids such as phosphatidylcholine and phosphatidylethanolamine [16]. The preference for cation binding weakens with the degree of hydrocarbon chain unsaturation and depends on the phase state of phospholipid (gel > liquid-crystal), e.g. for calcium one can find binding constants $\sim 1-400 \mathrm{M}^{-1}$ depending on the lipid and on the experimental method. Although the presence of anionic polyelectrolyte between lipid bilayers increases the binding constant significantly [17], the aggregates are "softly" packed and their resistance against the dissolution is lower in comparison to those prepared with cationic surfactants or cationic lipids $[6,18]$. A low affinity of zwitterionic phospholipids to cations and their high mobility are probably responsible for the structural variety of aggregates.

Generally, in a system DNA, DPPC and ion $^{2+}$ one must consider the following binding events (schematic): 
$\mathrm{DNA}+\mathrm{DPPC}+\mathrm{ion}^{2+} \longrightarrow\left\{\begin{array}{l}\mathrm{DPPC}+\mathrm{ion}^{2+} \\ \mathrm{DNA}+\mathrm{DPPC}+\mathrm{ion}^{2+} \\ \mathrm{DNA}+\mathrm{ion}^{2+}\end{array}\right.$

Within the present work, we focus to clarify structural parameters of DNA+DPPC+ion ${ }^{2+}\left(\mathrm{Ca}^{2+}\right.$, $\mathrm{Zn}^{2+}$ ) aggregates in the gel and liquid-crystalline phase. Calcium is physiologically relevant ion. Among the first-row transition metals, zinc is second only to iron in terms of abundance and importance in chemical, structural and regulatory roles in biological systems. Small-angle X-ray diffraction (SAXD) experiments were performed to examine the structural organization of the aggregates. The experiments revealed the need of small-angle neutron scattering (SANS) to determine the structural parameters of the aggregates and to understand gel-liquid-crystalline structural polymorphism in aggregates with zinc and short fragmented DNA. DNA concentration used in our experiments was low thus DNA+ion ${ }^{2+}$ did not contribute to the scattering patterns (SAXD and SANS).

\section{Experimental methods}

\subsection{The samples}

Highly polymerized calf thymus DNA ( $12 \mathrm{kbp}$, Sigma Chemicals Co., USA) and salmon sperm DNA (500-1000 bp, Applichem, Germany) were dissolved in $5 \mathrm{mM} \mathrm{NaCl}, \mathrm{pH} \sim 7$. The precise value of concentration was determined by measuring the absorbance $A_{\lambda}$ at wavelength $\lambda=260 \mathrm{~nm}$. The concentration of DNA is reported as nucleotides units. The purity of DNA was checked by measuring the absorbance $A_{\lambda}$ at $\lambda=260 \mathrm{~nm}$ and $280 \mathrm{~nm}$, both solutions of DNA have shown $A_{260} / A_{280}>1.7$ indicating a lack of contamination of DNA by proteins [19].

Dipalmitoylphosphatidylcholine (DPPC) was purchased from Avanti Polar Lipids, USA. Solutions of $\mathrm{CaCl}_{2}$ and $\mathrm{ZnCl}_{2}$ (Merck, Germany) were prepared in $5 \mathrm{mM} \mathrm{NaCl}, \mathrm{pH}$. Either redistilled water or $\mathrm{D}_{2} \mathrm{O}$ ( $99.9 \%$, Merck, Germany) were used for the preparation of solutions. Samples were prepared by hydration of a thin lipid film ( 5-10 mg of lipid per sample) with a solution of DNA and cations to obtain the required molar ratio lipid: DNA base and concentration of ions (more details in [13]). Multilamellar vesicles prepared from fully hydrated pure DPPC were used as reference sample. Unilamellar vesicles were prepared by extrusion of multilamellar vesicles using polycarbonate filter with pores of $50 \mathrm{~nm}$ diameter according to [20] and filled into $2 \mathrm{~mm}$ thick quartz cells (Hellma, Germany) for SANS.

\subsection{Methods}

Small-angle (SAXD) synchrotron radiation diffraction experiments were performed at the softcondensed matter beam line A2 at HASYLAB, DESY, Hamburg (Germany). The evacuated double-focusing camera was equipped with two linear delay line readout detectors. The SAXD detector was calibrated using rattail collagen [21]. The sample was equilibrated at each selected temperature for $5 \mathrm{~min}$ before exposure to radiation. Each diffraction peak of SAXD region was fitted with a Lorentzian above a linear background. The repeat distances were determined from the position of maximum of Lorentzians.

The SANS experiments were performed on the PAXE spectrometer in LLB CEA, Saclay, France. The sample to detector distance was $2.75 \mathrm{~m}$ and the neutron wavelength was $\lambda=6 \AA(\Delta \lambda / \lambda=10 \%)$ covering the scattering vector range $0.16-2.24 \mathrm{~nm}^{-1}$. The acquisition time for one sample was 40 minutes. The normalized SANS intensity $I(q)$ as a function of the scattering vector $q$ was obtained as described previously [22]. 


\section{Results and discussion}

\subsection{DPPC vesicles}

DPPC is a synthetic zwitterionic phospholipid, forming a lamellar phase (L) in excess of water (Fig. 1a). The temperature behaviour of DPPC is well known, with increasing temperature above $20{ }^{\circ} \mathrm{C}$ it forms the following phases: tilted gel $\mathrm{L}_{\beta^{\prime}} \rightarrow$ rippled gel $\mathrm{P}_{\beta} \rightarrow$ liquid-crystalline $\mathrm{L}_{\alpha}$, with the pretransition $\mathrm{T}_{\mathrm{p}} \approx 35^{\circ} \mathrm{C}\left(\mathrm{L}_{\beta} \rightarrow \mathrm{P}_{\beta}\right)$ and the main phase transition $\mathrm{T}_{\mathrm{t}} \approx 42{ }^{\circ} \mathrm{C}\left(\mathrm{P}_{\beta} \rightarrow \mathrm{L}_{\alpha}\right)[23,24]$. We focus our study on the gel phase $\left(20^{\circ} \mathrm{C}\right)$ and on the liquid-crystalline phase $\left(50{ }^{\circ} \mathrm{C}\right)$. The obtained repeat distances $(d)$ are given in the Tab. 1. To understand the structural changes of DPPC+DNA+cation aggregates, it is necessary to look at the structural parameters in more detail. The repeat distance $d$ is the sum

$$
d=d_{L}+d_{W}
$$

where $d_{L}$ is the lipid bilayer thickness and $d_{W}$ is the thickness of the aqueous layer between neighbouring bilayers which is filled with DNA strands. Thermodynamically, the lipid - water mixture is a two phase system: lipid+water trapped between lipid's lamellae and the bulk water. Not all added water is located between lipid bilayers (with a uniform spacing), thus to determine the $d_{L}$ and $d_{W}$ from the repeat distance ( $d$ ) obtained by SAXD experiment is difficult (see e.g. [25]). We employ SANS to obtain the lipid bilayer thickness $d_{L}$.

For dispersions of monodisperse centrosymmetric particles, the SANS intensity is given by

$$
I(q)=N_{P} \cdot|F(q)|^{2} \cdot S(q)
$$

where $q$ is the scattering vector $q=4 \pi \sin \theta / \lambda, 2 \theta$ the scattering angle, $N_{P}$ the number density of particles, $F(q)$ their form factor and $S(q)$ the interparticle structure factor. The multilamellar stacking gives rise to the interaction peak, in $S(q)$. However, the interparticle structure factor $S(q)$ is approximately equal to 1 for dilute and weakly interacting particles, what is a good approximation for unilamellar vesicles at PC concentrations <2 wt. \% [26, 27]. The model of weakly interacting particles describes well unilamellar vesicles prepared by extrusion [28]. A typical SANS curve of unilamellar vesicles prepared by extrusion is shown in Fig. 2a. However, unilamellar vesicles are also formed spontaneously when the surface charge density is higher than $1-2 \mu \mathrm{C} / \mathrm{cm}^{2}$ [29], e.g. multilamellar DPPC dispersion in $1 \mathrm{mM} \mathrm{CaCl}_{2}$ completely converts into unilamellar vesicles [30, 31]. Fig. 2b shows unilamellar DPPC vesicles formed spontaneously in $20 \mathrm{mM} \mathrm{ZnCl}$.

The SANS curves (Fig. 2) were analyzed using a strip-function model of the phospholipid bilayer [32]. In this model, the bilayer is divided into three strips corresponding to two polar head group regions, $d_{H}$, (one on each side of the bilayer) and the bilayer centre spanning the hydrocarbon region $\left(d_{C}\right)$. The form factor $F(q)$ is the Fourier transform of the contrast $\Delta \rho(r)$ between the coherent neutronscattering length density (SLD) of the bilayer and the solvent. For unilamellar vesicles bilayer, the strip model is given by:

$$
F(q)=4 \pi \sum_{i=1}^{3} \int_{R_{i-1}}^{R_{i}} \Delta \rho_{i} \frac{\sin (q r)}{q r} r^{2} d r
$$

where $\Delta \rho_{i}(r)$ is the SLD contrast and $\Delta d_{i}=R_{i}-R_{i-1}$ is the thickness of the $i$-th strip. The total lipid bilayer thickness $d_{L}$ is then given by $d_{L}=2 d_{H}+d_{C}$. The SLD profile of the bilayer model is depicted in Fig. 2, Inset A. In addition to $d_{L}$, the model includes the number of water molecules $n_{W}$ located in the head group of the lipid, and the surface area per 1 lipid molecule on water lipid interface $A_{L}$. The obtained structural parameters of the DPPC bilayer and DPPC+20 mM ZnCl 2 are given in the Tab. 2 . In addition, Tab. 2 shows structural parameters of DPPC $+1 \mathrm{mM} \mathrm{CaCl}_{2}$ taken from [33] where the model is described in more detail.

\subsection{DNA+DPPC+cation aggregates}

Representative diffractograms of the structures observed in DNA+DPPC+ion ${ }^{2+}$ aggregates are represented in Fig. 1b-i. The diffractogram of the aggregate DPPC:DNA=3:1 mol/base prepared at 

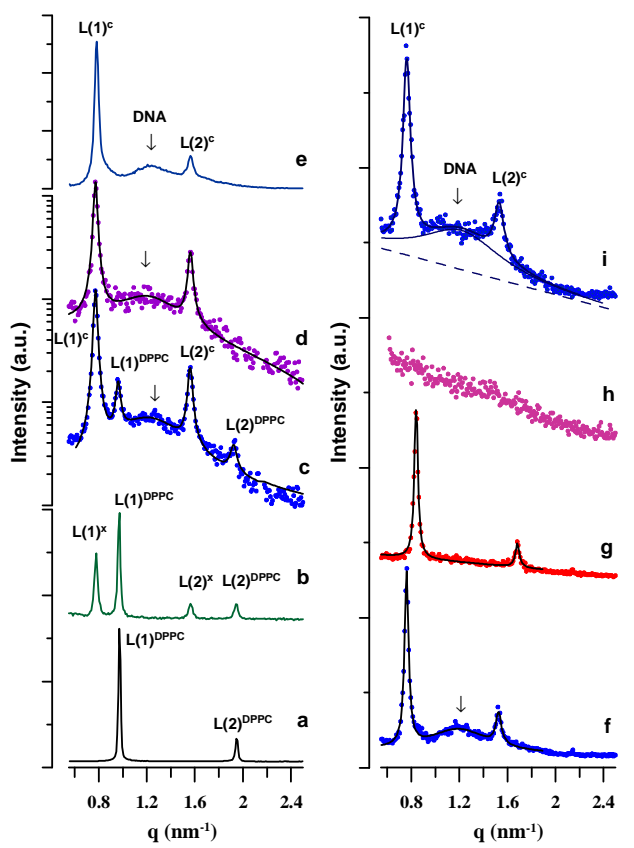

Fig. 1 SAX diffractograms of multilamellar DPPC vesicles, $20{ }^{\circ} \mathrm{C}$ (a), and DNA+DPPC aggregates at: 1 $\mathrm{mM} \mathrm{CaCl} 2,20{ }^{\circ} \mathrm{C}(\mathrm{b}), 2 \mathrm{mM} \mathrm{CaCl}, 20{ }^{\circ} \mathrm{C}$ (c), $2 \mathrm{mM}$ $\mathrm{CaCl}_{2}, 37{ }^{\circ} \mathrm{C}(\mathrm{d}), 20 \mathrm{mM} \mathrm{CaCl}_{2}, 20{ }^{\circ} \mathrm{C}$ (e), $20 \mathrm{mM}$ $\mathrm{ZnCl}_{2}, 20^{\circ} \mathrm{C}$ (f), $20 \mathrm{mM} \mathrm{ZnCl}_{2}, 50^{\circ} \mathrm{C}$ (g), $20 \mathrm{mM} \mathrm{ZnCl}_{2}$, $50{ }^{\circ} \mathrm{C}$ (DNA, 500-1000 bp) (h), $20 \mathrm{mM} \mathrm{ZnCl} 2,20{ }^{\circ} \mathrm{C}$ (DNA, 500-1000 bp), after heating (i)

tions $\left(0-76.5 \mathrm{mM}\right.$ of $\mathrm{Ca}^{2+}$ or $\left.\mathrm{Mg}^{2+}\right)$, and similar strutures coexistence of two phases can be explained by a lateral segregation of DNA and metal cations. It was

Tab. 1 The structural parameters of DNA+DPPC+cation aggregates.

\begin{tabular}{|c|c|c|c|c|c|c|c|}
\hline $\begin{array}{l}\text { DPPC:DNA } \\
\text { (mol:base) }\end{array}$ & DNA & cation & $\begin{array}{c}c \\
(\mathrm{mM})\end{array}$ & $\begin{array}{c}t \\
\left({ }^{\circ} \mathrm{C}\right)\end{array}$ & $\begin{array}{c}d \\
(\mathrm{~nm})\end{array}$ & $\begin{array}{c}d_{D N A} \\
(\mathrm{~nm})\end{array}$ & $\begin{array}{c}d_{D P P C} \\
(\mathrm{~nm})\end{array}$ \\
\hline $1: 0$ & - & - & - & 20 & - & - & $6.33 \pm 0.01$ \\
\hline $1: 0$ & - & - & - & 50 & - & - & $6.59 \pm 0.01$ \\
\hline $3: 1$ & $\mathrm{hp}$ & $\mathrm{Ca}$ & 1 & 20 & $8.04 \pm 0.01$ & - & $6.49 \pm 0.01$ \\
\hline $3: 1$ & $\mathrm{hp}$ & $\mathrm{Ca}$ & 1 & 50 & $7.77 \pm 0.01$ & - & $6.84 \pm 0.01$ \\
\hline $3: 1$ & $\mathrm{hp}$ & $\mathrm{Ca}$ & 2 & 20 & $8.07 \pm 0.02$ & $5.18 \pm 0.07$ & $6.54 \pm 0.01$ \\
\hline $3: 1$ & $\mathrm{hp}$ & $\mathrm{Ca}$ & 2 & 37 & $8.06 \pm 0.03$ & $5.23 \pm 0.07$ & - \\
\hline $3: 1$ & $\mathrm{hp}$ & $\mathrm{Ca}$ & 2 & 50 & $7.65 \pm 0.02$ & - & - \\
\hline $3: 1$ & $\mathrm{hp}$ & $\mathrm{Ca}$ & 20 & 20 & $8.02 \pm 0.01$ & $5.11 \pm 0.03$ & - \\
\hline $3: 1$ & $\mathrm{hp}$ & $\mathrm{Ca}$ & 20 & 50 & $7.55 \pm 0.01$ & $5.02 \pm 0.11$ & - \\
\hline $3: 1$ & $\mathrm{hp}$ & $\mathrm{Zn}$ & 20 & 20 & $8.24 \pm 0.06$ & $5.27 \pm 0.04$ & - \\
\hline $3: 1$ & $\mathrm{hp}$ & $\mathrm{Zn}$ & 20 & 50 & $7.47 \pm 0.01$ & - & - \\
\hline $3: 1$ & short* & $\mathrm{Zn}$ & 20 & 20 & $8.13 \pm 0.02$ & $6.55 \pm 1.28$ & - \\
\hline $3: 1$ & short* & $\mathrm{Zn}$ & 20 & 50 & - & - & - \\
\hline $3: 1$ & short* & $\mathrm{Zn}$ & 20 & 20 & $8.21 \pm 0.01$ & $5.12 \pm 0.08$ & - \\
\hline
\end{tabular}

hp - highly polymerized calf thymus DNA; short* - salmon sperm DNA 500-1000 bp
$1 \mathrm{mM} \mathrm{Ca}^{2+}$ (Fig. 1b) represents a superposition of two one-dimensional periodic structures. The reflections $\mathrm{L}(1)^{\mathrm{x}}$ and $\mathrm{L}(2)^{\mathrm{x}}$ correspond to the lamellar phase $\left(\mathrm{L}^{\mathrm{x}}\right)$, with the repeat distance $d_{L x}=8.04 \mathrm{~nm}$ at $20^{\circ} \mathrm{C}$. Subtracting the DPPC lipid bilayer thickness $d_{L}=5.38 \mathrm{~nm}$ (Tab. 2), the interlamellar thickness $d_{W} 2.66 \mathrm{~nm}$ offers enough space for DNA strands (with diameter $\sim 2 \mathrm{~nm}$ ) to be intercalated in the water layers between the DPPC bilayers. We do not observe any DNA reflection. Because the packing of DNA strands in this phase is not obvious, we use the abbreviation $\mathrm{L}^{\mathrm{x}}$. The reflections $\mathrm{L}(1)_{\mathrm{DPPC}}$ and $\mathrm{L}(2)_{\mathrm{DPPC}}$ were identified as the second lamellar phase $\left(\mathrm{L}_{\mathrm{DPPC}}\right)$, with the periodicity $d_{D P P C}=6.49 \mathrm{~nm}$. Applying the same procedure as above, one finds the interlamellar thickness $d_{W} \sim 1.2 \mathrm{~nm}$ that does not offer enough space for DNA strands. Moreover, already $1 \mathrm{mM} \mathrm{CaCl} 2$ promotes formation of unilamellar DPPC vesicles that we do not see in the SAXD pattern because of the absence of long-range organization $[30,31]$. The repeat distance of $\mathrm{L}_{\mathrm{DPPC}}$ phase, $d_{D P P C}=6.49 \mathrm{~nm}$, detected in the $\mathrm{DPPC}+\mathrm{DNA}+\mathrm{Ca}^{2+}$ aggregate thus indicates no presence of $\mathrm{Ca}^{2+}$ ions. The existence of a "pure" phosphatidylcholine phase in samples prepared in solution of divalent cations is rather surprising. Our previous work [12] documents that such structure forms also in DOPC + DNA aggregates in a wide range of cations concentra- 
suggested that the presence of negatively charged DNA between bilayers can induce a partial lateral segregation of cationic amphiphiles in bilayers to minimize the electrostatic energy of the whole system, i.e. lateral "demixing" in the plane of the bilayers can occur [34, 35].

Fig. 1c and d show diffractograms of DPPC:DNA=3:1 mol/base aggregate prepared in $2 \mathrm{mM}$ $\mathrm{Ca}^{2+}$ solution at 20 and $37{ }^{\circ} \mathrm{C}$, respectively. The intensities are plotted in logarithmic scale. Full line corresponds to a curve resulting from a superposition of 3 (or 5) Lorentzians above a linear background obtained by fitting of diffraction maxima. We identify again the coexistence of two lamellar phases: $\mathrm{L}_{\mathrm{DPPC}}$, formed by lipid bilayers without DNA and $\mathrm{Ca}^{2+}$ ions, and the second phase, which is a condensed lamellar phase $\mathrm{L}^{\mathrm{c}}$ with regularly organized DNA strands of periodicity $d_{D N A} \sim 5 \mathrm{~nm}$. A small increase in $\mathrm{Ca}^{2+}$ concentration improved the organization of DNA strands inside of $\mathrm{L}^{\mathrm{x}}$ phase, although the DNA peak is broad $\left(\Delta s_{D N A} \sim 0.06 \mathrm{~nm}^{-1}\right)$, indicating a poor organization of the DNA lattice. Heating the aggregate, we observe the decrease in the intensity of both reflections of $\mathrm{L}_{\text {DPPC }}$ phase. At $\sim 37^{\circ} \mathrm{C}$, the $\mathrm{L}_{\text {DPPC }}$ phase "dissolved" completely, the diffractogram shows only the $\mathrm{L}^{\mathrm{c}}$ phase (Fig. 1d). The structural parameters are given in Tab. 1.

DNA+DPPC in $20 \mathrm{mM} \mathrm{Ca}^{2+}$ (DPPC:DNA=3:1 mol/base) at $20{ }^{\circ} \mathrm{C}$ shows a condensed lamellar phase $\mathrm{L}_{\beta}{ }^{\mathrm{c}}$ with well defined DNA peak at $q \sim 1.23 \mathrm{~nm}^{-1}$ (Fig. 1e). The same phase is formed, when the aggregates were prepared in $20 \mathrm{mM} \mathrm{ZnCl}_{2}$ (Fig. 1f). Structural parameters of the aggregates are given in Tab. 1. When heating the aggregates to higher temperatures, we have observed an increase in the DNA peak width and a decrease of its intensity, which gradually disappears in the background (see also [13]). The typical diffractogram DNA+DPPC + ion $^{2+}$ aggregates prepared with highly polymerized calf thymus DNA at temperatures $t \geq 50{ }^{\circ} \mathrm{C}$ is shown in Fig. $1 \mathrm{~g}$. In the liquid-crystalline state, the $\mathrm{L}_{\alpha}{ }^{\mathrm{c}}$ converts to the $\mathrm{L}^{\mathrm{x}}$ phase with unknown organization of DNA strands. However, the aggregates $\mathrm{DNA}+\mathrm{DPPC}+\mathrm{Zn}^{2+}$ prepared with short fragmented salmon sperm DNA (500-1000 bp) in liquidcrystalline phase have lost their long-range order completely, and we do not observe any diffraction pattern (Fig. 1h). After cooling the sample back to $20{ }^{\circ} \mathrm{C}$, the regular organization of the aggregate is rebuilt (Fig. 1i). Such temperature behaviour have shown aggregates with $\mathrm{ZnCl}_{2}$ at concentrations above $15 \mathrm{mM}$. In Fig. $2 \mathrm{c}$, the SANS curve of the DNA+DPPC $+\mathrm{Zn}^{2+}$ mixture in the liquid-crystalline

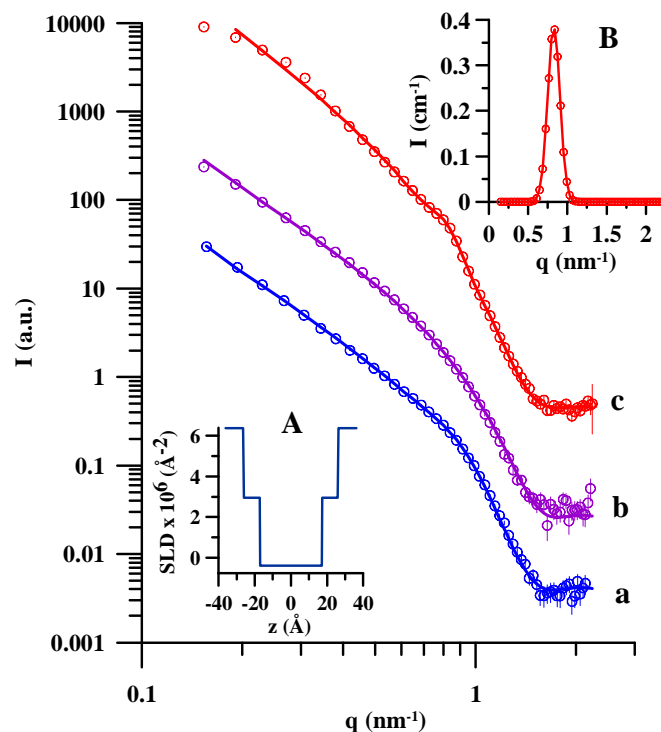

Fig. 2 The SANS curves of DPPC unilamellar vesicles, (a), DPPC+20 $\mathrm{mM} \quad \mathrm{ZnCl}_{2}$ (b), DNA+DPPC+20 $\mathrm{mM} \mathrm{ZnCl}_{2}$ (c) at $50{ }^{\circ} \mathrm{C}$. Full lines represent the best fits. Inset A: SLD profile of the lipid bilayer model. Inset B: $S(q)-1$ extracted analytically from curve c. state (at $50{ }^{\circ} \mathrm{C}$ ) shows the scattering due to polydisperse hollow spheres, i.e. unilamellar vesicles. The curve is slightly deformed in low $q$ region, and a small peak is obvious in the middle $q$-region. The experimental points were fitted by the strip function model. The full line in Fig. 2c represents the best fit, when $S(q)=1+G(q)$, where $G(q)$ is a Gaussian included into the model. The inset B in Fig. 2 displays the peak extracted from the curve when the separation of the form and the structure factor is done analytically. The maximum of the peak at $q_{0} \sim 0.83 \mathrm{~nm}^{-1}$ correlates well with the periodicity of the DNA+DPPC $+\mathrm{Zn}^{2+}$ aggregate (Tab.1). The low intensity of the peak indicates a negligible volume fraction of organized structure in the mixture. The shape of the curve in low $q$-region is affected by the radius of unilamellar vesicles and their polydispersity [32]. A small misfit between the experiment and the model at low $q$ could result from a deformation of $\mathrm{DPPC}+\mathrm{Zn}^{2+}$ vesicles due to DNA binding. The structural parameters are summarized in Tables 1 and 2. The SANS experiment thus revealed dissolution of the DNA+DPPC $+\mathrm{Zn}^{2+}$ condensed lamellar phase when the lipid is in the liquid- 
crystalline state. We identified unilamellar $\mathrm{DPPC}+\mathrm{Zn}^{2+}$ vesicles, although a small volume fraction of the mixture keeps the organized structure. DNA polyanion released from the aggregate due to dissolution is neutralized by $\mathrm{Zn}^{2+}$ ions. The contrast between $\mathrm{DNA}+\mathrm{Zn}^{2+}$ and $\mathrm{D}_{2} \mathrm{O}$ at the used DNA concentration is low and thus its contribution to the SANS intensity is negligible. The aggregates with $\mathrm{Ca}^{2+}$ were stable against the dissolution up to $80{ }^{\circ} \mathrm{C}$. The observed temperature behaviour of aggregates could result from the different size of the cations, and due to differences in their electronic structure. Their localization in the DPPC head group is different [36] as well as their binding to DNA [37]. However, the aggregates with calf thymus DNA are stable up to $\sim 90{ }^{\circ} \mathrm{C}$, regardless the length of its fragments [12], thus the origin of DNA could play a role in the effect as well.

Tab. 2 Structural parameters of DPPC unilamellar vesicles.

\begin{tabular}{|c|c|c|c|c|c|}
\hline & $t\left({ }^{\circ} \mathrm{C}\right)$ & $d_{L}(\mathrm{~nm})$ & $A_{L}\left(\mathrm{~nm}^{2}\right)$ & $n_{W}(\mathrm{~mol} / \mathrm{mol})$ & $q_{0}\left(\mathrm{~nm}^{-1}\right)$ \\
\hline DPPC & 50 & $4.80 \pm 0.05$ & $0.61 \pm 0.01$ & $7.5 \pm 0.3$ & - \\
\hline $\mathrm{DPPC}+1 \mathrm{mM} \mathrm{Ca}^{2+}$ & 20 & $5.38 \pm 0.05$ & $0.46 \pm 0.06$ & $2.9 \pm 0.2$ & - \\
\hline $\mathrm{DPPC}+20 \mathrm{mM} \mathrm{Zn^{2+ }}$ & 50 & $5.11 \pm 0.15$ & $0.57 \pm 0.02$ & $7.4 \pm 0.6$ & - \\
\hline $\mathrm{DNA}+\mathrm{DPPC}+20 \mathrm{mM} \mathrm{Z \textrm {Zn } ^ { 2 + }}$ & 50 & $5.15 \pm 0.24$ & $0.57 \pm 0.04$ & $7.7 \pm 0.9$ & $0.83 \pm 0.01$ \\
\hline
\end{tabular}

4 Conclusion

Our experiments document structural heterogeneity of DNA+DPPC+metal cation $\left(\mathrm{Ca}^{2+}, \mathrm{Zn}^{2+}\right)$ aggregates as a function of cation concentration, temperature as well as the length of DNA fragments. Aggregates were prepared at milimolar concentrations of divalent cations that are physiologically relevant. The reversible effect of the aggregate dissolution (condensed lamellar phase $\mathrm{L}_{\beta}^{\mathrm{c}} \leftrightarrow$ unilamellar DPPC vesicles + DNA), induced by phase transition of the lipid was not reported in the literature yet. Our experiments may help in the understanding of the relation between the structure and transfection activity of gene delivery vehicles that is one of the main aims of the research in this field.

Acknowledgements: This work was supported by the European Community under the FP6 "Structuring the European Research Area" Programme: RII3-CT-2004-506008 (IA-SFS) (HASYLAB project II-20052037 EC); by the JINR project 07-4-1069-09/2011 and by the VEGA grant 1/0292/06 to DU.

\section{References}

1. Y. Sato, N. Kumazawa, K. Yoshikawa, Y. Kurusu, Biosci. Biotechnol. Biochem. 69, 235 (2005)

2. V.G. Budker, Y.A. Kazatchkov, L.P. Naumova. FEBS Letters 95, 143 (1978)

3. L. Vojčíková, P. Balgavý, Stud. Biophys. 125, 5 (1988)

4. L. Vojčíková, E. Švajdlenka, P. Balgavý, Gen. Physiol. Biophys. 8, 399 (1989)

5. R.S. Khusainova, K.A. Dawson, I. Rochev, A.V. Gorelov, G.R. Ivanitskii, Dokl. Akad. Nauk 367, 553 (1999)

6. D. Uhríková, M. Kovářová, P. Balgavý, Acta Facult. Pharm. Univ. Comenianae 51, 217 (2004)

7. L. Vojčíková, P. Balgavý, Acta Facult. Pharm. Univ. Comenianae 52, 226 (2005)

8. Y.S. Tarahovsky, A.V. Khusainova, A.V. Gorelov, T.I. Nicolaeva, A.A. Deev, A.K. Dawson, G.R. Ivanitsky, FEBS Letters 390, 133 (1996)

9. D. Uhríková, G. Rapp, P. Balgavý, in Challenges for Coordination Chemistry in the new Century, edited by M. Melník, A. Sirota, (Bratislava, 2001), p. 219

10. O. Francescangeli, V. Stanic, L. Gobbi, P. Bruni, M. Iacussi, G. Tosi, S. Bernstorff, Phys. Rev. E 67, art 011904 (2003)

11. J. McManus, J.O. Rädler, K.A. Dawson, Langmuir 19, 9630 (2003)

12. D. Uhríková, M. Hanulová, S.S. Funari, R.S. Khusainova, F. Šeršeň, P. Balgavý, Biochim. Biophys. Acta 1713, 15 (2005)

13. D. Uhríková, A. Lengyel, M. Hanulová, S.S. Funari, P. Balgavý, Eur. Biophys. J. 36, 363 (2007)

14. J.C. Shepherd, G. Büldt, Biochim Biophys Acta 514, 83 (1978)

15. Y. Izumitani, J. Colloid Interface Sci. 166, 143 (1994)

16. Ch. Altenbach, J. Seelig, Biochemistry 23, 3913 (1984)

17. D. Huster, K. Arnold, Biophys. J. 75, 909 (1998) 
18. D. Uhríková, L. Benkovičová, M. Kovářová, P. Balgavý, in Book of abstract of the XXIV.Days of Medical Biophysics, (Mozolov, Czech Republic, 2001), p.65

19. T. Maniatis, E. Fritsch, J. Sambrook, in Molecular cloning, A laboratory manual, Cold Spring Harbor Laboratory, 1982

20. R.C. MacDonald, R.I. MacDonald, B.Ph.M. Menco, K. Takeshita, N.K. Subbarao, L.R.Hu, Biochim. Biophys. Acta 1061, 297 (2001)

21. N. Roveri, A. Bigi, P.P. Castellani, E. Foresti, M. Marchini, R.Strocchi, Boll. Soc. Ital. Biol. Sper. 56, 953 (1980)

22. N. Kučerka, D. Uhríková, J. Teixeira, P. Balgavý, Acta Facult. Pharm. Univ. Comenianae 50, 78 (2003)

23. N. Albon, J.M. Sturtevant, Proc. Natl. Acad. Sci. U. S. A 75, 2258 (1978)

24. J. Stümpel, H.J. Eibl, A. Nicksch, Biochim Biophys Acta 727, 246 (1983)

25. J.F. Nagle, S. Tristram-Nagle, Biochim. Biophys. Acta 1469, 159 (2000)

26. W. Knoll, J. Haas, H.B. Sturhrmann, H.H. Fuldner, H. Vogel, E. Sackmann, J. Appl. Cryst. 14, 191 (1981)

27. T. Nawroth, H. Conrad, K. Dose, Physica B 156\&157, 477 (1989)

28. P. Balgavý, M. Dubničková, D. Uhríková, S. Yaradaikin, M. Kiselev, V.Gordeliy, Acta Physica Slovaca 48, 509 (1998)

29. H. Hauser, in Phospholipid Handbook, edited by G. Cevc, (Marcel Dekker Inc., New York, 1993) p. 603

30. Y. Inoko, T. Yamaguchi, K. Furuya, T. Mitsui, Biochim Biophys Acta 413, 24 (1975)

31. D. Uhríková, J. Teixeira, A. Lengyel, L. Almásy, P. Balgavý, Spectroscopy 21, 43 (2007)

32. N. Kučerka, J.F. Nagle, S.E. Feller, P. Balgavý, Phys. Rev. E 69, 051903 (2004)

33. D. Uhríková, N. Kučerka, J. Teixeira, V. Gordeliy, P. Balgavý, Chem. Phys. Lipids 155, 80 (2008)

34. R. Bruinsma, J. Mashl, Europhys. Lett. 41, 165 (1998)

35. D. Harries, S. May, W.M. Gelbart, A. Ben Shaul, Biophys. J. 75, 159 (1998)

36. H. Binder, O. Zschornig, Chem. Phys. Lipids 115, 39 (2002)

37. N. Gresh, J. Šponer, J. Phys. Chem. B 103, 11415 (1999) 